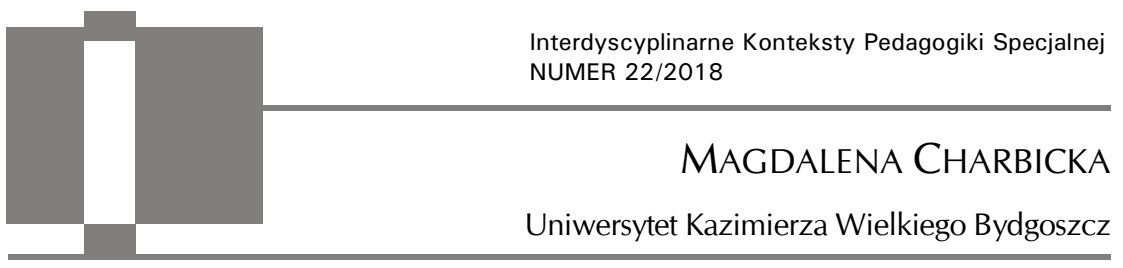

\title{
Zabawa dzieci z autyzmem w oddziaływaniach terapeutycznych - instrumentalna czy autoteliczna?
}

\begin{abstract}
Magdalena Charbicka, Zabawa dzieci z autyzmem w oddziaływaniach terapeutycznych - instrumentalna czy autoteliczna? [Play in autistic children in therapeutic wards - instrumental or autotelic?]. Interdyscyplinarne Konteksty Pedagogiki Specjalnej, nr 22, Poznań 2018. Pp. 105-125. Adam Mickiewicz University Press. ISSN 2300-391X. DOI: https://doi.org/10.14746/ikps.2018.22.06

Play is a typical and natural activity in children, which introduces it to the real world. It plays an uncommonly important function, thanks to the which the little person learns and gains information about their environment, the properties of objects, social relations or other rules. This area is different in children with autism. In most cases, play is accompanied by significant deficits, and the burden of focus of revalidation influences remains on the development of areas that are more disturbed, such as communication, disturbances in social interactions or behaviour hindering functioning. In course of therapeutic work, we sometimes forget the seemingly trivial activity that the playing of a child may be in view of adults. Considering this, it is worthwhile to take a look at the role ascribe to play by specialists over the years, and what it looks like in autistic children.
\end{abstract}

KEY WORDS: autism, child, children playing, play in children, development, types of play, social skills 


\title{
Problematyka autyzmu jako zjawiska społecznego
}

\author{
Dziecko nie bawi się dlatego, że jest dzieckiem, \\ ale bawi się dlatego, by stać się dorostym.
}

Lew S. Wygotski

Autyzm jest całościowym zaburzeniem rozwoju, którego podłoże ma charakter neurobiologiczny. Obecnie na świecie obowiązują dwie klasyfikacje służące stawianiu rozpoznania. Jest to klasyfikacja zaburzeń psychicznych Amerykańskiego Towarzystwa Psychiatrycznego DSM-5 opublikowana w 2013 r. oraz obowiązująca od 1996 r. i nadal wykorzystywana w Polsce Międzynarodowa Statystyczna Klasyfikacja Chorób i Problemów Zdrowotnych ICD-10, opracowana przez Światową Organizację Zdrowia (w zaawansowanej fazie przygotowania przez WHO jest wersja ICD-11). W obydwu narzędziach występują pewne różnice w kryteriach diagnostycznych oraz w nazewnictwie jednostek chorobowych. Cytując za Agnieszką Rynkiewicz i Martą Kulik,

w klasyfikacji DSM-5 scalono wszystkie jednostki diagnostyczne w jedną wspólną jednostkę o nazwie zaburzenie ze spektrum autyzmu (ASD, Autism Spectrum Disorder). (...) „Spektrum” odnosi się do różnic $\mathrm{w}$ prezentacji i nasileniu symptomów wewnątrz grupy pacjentów z ASD oraz wskazuje na kontinuum pomiędzy populacją ogólną a osobami z tą diagnozą ${ }^{1}$.

Zgodnie z klasyfikacją ICD-10 rozpoznawane jednostki, które podlegają procesowi orzeczniczemu dla potrzeb uzyskania wsparcia w systemie edukacyjnym z tytułu potrzeby kształcenia specjalnego, to: autyzm, zespół Aspergera czy autyzm atypowy². W celu

${ }^{1}$ A. Rynkiewicz, M. Kulik, Wystandaryzowane, interaktywne narzędzia do diagnozy zaburzeń ze spektrum autyzmu a nowe kryteria diagnostyczne DSM-5, "Psychiatria” 2013, tom 10, nr 2, s. 41-48.

$2 \mathrm{~W}$ praktyce orzeczniczej jako autyzm rozpoznaje się także autyzm atypowy, nie spełniający wszystkich kryteriów diagnostycznych autyzmu dziecięcego. 
zachowania spójności, w niniejszym artykule dla wszystkich zaburzeń używany będzie termin ASD scalający prezentowane zagadnienia.

Na przestrzeni ostatnich 10 lat temat autyzmu zgłębiany i analizowany jest wielokierunkowo, od coraz lepszych i odpowiadających na wiele pytań badań przez stale zwiększającą się liczbę publikacji aż do wszechstronnie propagowanej wiedzy. Zwiększa się świadomość społeczeństwa, zwiększa się również liczba dzieci, młodzieży i dorosłych, $\mathrm{u}$ których rozpoznawane jest to zaburzenie. Jak wynika z raportu przedstawionego przez amerykańskie organizacje zajmujące się monitorowaniem zaburzeń rozwoju osób znajdujących się $\mathrm{w}$ spektrum $\mathrm{ASD}^{3}$, szacowany procent stawianych diagnoz jest wyższy niż w poprzednich raportach. Badania przeprowadzone w 11 amerykańskich stanach wykazały, że u jednego na 59 dzieci w wieku 8 lat zidentyfikowano zaburzenia ASD ${ }^{4}$. W Europie i w Polsce badania statystyczne tak szczegółowe nie są prowadzone, jednak przyjmuje się, że zaburzenia z ASD diagnozowane są u jednego na 100 dzieci5. Pierwsze badania mające za zadanie oszacować rozpowszechnienie ASD w Europie prowadzone są w dwunastu krajach europejskich przez Autism Spectrum Disorders in European Union od 2016 r. i na wynik ostateczny będzie trzeba jeszcze poczekać6.

Żeby przybliżyć problematykę występowania ASD w Polsce, a tym samym wskazać wagę poruszanego zagadnienia, odwołano się do danych statystycznych zawierających informacje na temat liczby uczniów objętych wsparciem edukacyjnym, czyli posiadają-

${ }^{3}$ Funded by the Centers for Disease Control and Prevention (CDC), United States Department of Health and Human Services https:/ / www.cdc.gov [dostęp: 16.05. 2018].

${ }^{4}$ Community Report from the Autism and Developmental Disabilities Monitoring (ADDM) Network, https://www.cdc.gov/ncbddd/autism/addm-community-report/ documents/addm-community-report-2018-h.pdf [dostęp: 12.05.2018].

${ }^{5}$ Pewne różnice epidemiologiczne mogą wynikać z samego faktu odwołania się do dwóch różnych klasyfikacji: DSM w USA i ICD w Europie, w tym w Polsce.

${ }^{6}$ http:/ / asdeu.eu/wp-content/uploads/2016/09/Poster-ASDEU-Prevalence_ AE-Congress.pdf [dostęp: 12.05.2018]. 
cych orzeczenie o potrzebie kształcenia specjalnego wydanego przez publiczne Poradnie Psychologiczno-Pedagogiczne z uwagi na autyzm, zespół Aspergera. Proces wzrostu liczby wydawanych orzeczeń ilustruje wykres nr 1.

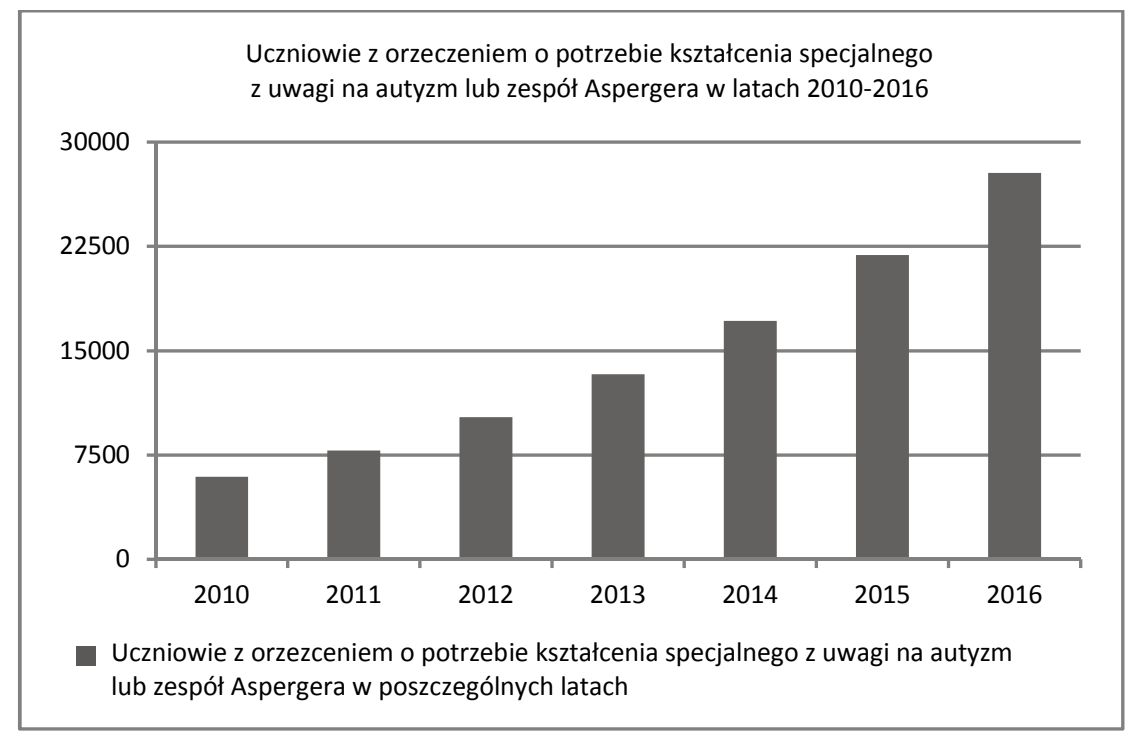

Wykres 1. Uczniowie z orzeczeniem o potrzebie kształcenia specjalnego, wydanego przez PPP z uwagi na diagnozę ASD w latach 2010-2016 (opracowanie własne na podstawie danych $\mathrm{SIO})^{7}$

Dane przedstawione na wykresie dotyczą wszystkich typów placówek edukacyjnych, składających sprawozdanie w Systemie Informacji Oświatowej na dzień 30 września w poszczególnych latach. Podkreślić należy, że odnoszą się one do rubryki autyzmu i zespołu Aspergera, a nie zawierają informacji z rubryki, w której wpisywani są uczniowie z niepełnosprawnością sprzężoną, wśród

7 SIO https://cie.men.gov.pl/sio-strona-glowna/dane-statystyczne/niepelnospraw nosci-dane-statystyczne/ [dostęp: 16.05.2018]. 
których mogą znajdować się również uczniowie z autyzmem i niepełnosprawnością intelektualną. W 2016 r. dane zebrane z Systemu Informacji Oświatowej wskazały, że liczba dzieci posiadających orzeczenie o potrzebie kształcenia specjalnego z uwagi na autyzm czy zespól Aspergera, przebywających w placówkach wychowania przedszkolnego sięgała prawie $10000^{8}$. Ponieważ zabawa stanowi podstawową aktywność dziecka wieku przedszkolnym, a w spektrum zaburzeń autystycznych jej rozwój przebiega nieprawidłowo, zagadnieniu zabawy poświęcona będzie dalsza część niniejszego opracowania.

\section{Charakterystyka zabawy dziecka z ASD}

Specyfika funkcjonowania dziecka z ASD, a także cechy je charakteryzujące, są zróżnicowane pod względem liczby występujących zachowań, ich natężenia i jakości, a także możliwości poznawczych, komunikacyjnych czy sprawności intelektualnej. Biorąc pod uwagę rozpiętość cech, użycie określenia "autystyczne spektrum zaburzeń" sformułowane przez Doris A. Allen w 1988 r. wydaje się być zasadne ${ }^{9}$. Badania prowadzone przez Lornę Wing w latach 80. „wykazały rozpowszechnienie autyzmu na poziomie 4-5 przypadków na 10000 osób. Jednocześnie po przeprowadzeniu tego samego badania pod kontem kontinuum autystycznego wskaźnik ten wzrasta do 21 na $10000^{\prime \prime 10}$. Obserwacja takiej grupy dzieci pozwoliła na wyodrębnienie trzech charakterystycznych sfer, które opisane szczegółowo weszły w skład klasyfikacji diagnostycznych, o których pisano wcześniej. Wyszczególnione przez Lornę Wing sfery, w których wszystkie badane dzieci przejawiały nieprawidłowości to:

- problemy z uczestniczeniem $\mathrm{w}$ naprzemiennej interakcji społecznej,

8 Ibidem.

${ }^{9}$ E. Pisula, Małe dziecko z autyzmem. Diagnoza i terapia. Gdańskie Wydawnictwo Psychologiczne, Gdańsk 2005.

10 Ibidem. 
- trudności z komunikowaniem się z otoczeniem,

- specyficzny, ograniczony wzorzec wyobraźni, który wpływa min. na sztywność w zabawie ${ }^{11}$.

W rozwoju dziecka zabawa odgrywa istotną rolę. Jest pierwszą i niezwykle ważną aktywnością dziecka, która przybliża je do zdobywania wiedzy o otaczającym świecie. Analizując rozważania psychologów na temat zabawy, można wyróżnić następujące właściwości, jakie ją charakteryzują:

- jest zjawiskiem społecznym, powstaje i rozwija się pod wpływem otoczenia i własnej aktywności dziecka;

- ma charakter historyczny - zmienia się i kształtuje w zależności od warunków, w jakich dziecko się wychowuje. Może zmieniać się treść i tematyka zabawy;

- jest odzwierciedleniem poznawanej przez dziecko rzeczywistości ${ }^{12}$.

Zabawa stanowi podstawę interakcji społecznych kształtujących się właściwie już od bardzo wczesnego okresu życia. Dziecko zaangażowane w aktywność zabawową uczy się umiejętności życiowych niezbędnych do funkcjonowania w dorosłym świecie. $W$ toku rozwoju dziecko przechodzi przez różne etapy, zabawy przypisane poszczególnym przedziałom wiekowym. W pierwszych miesiącach angażuje się głównie w zabawę własnym ciałem i manipulowanie przedmiotami, następnie przechodzi do zabaw konstrukcyjnych, tematycznych, by w wieku sześciu lat osiągnąć umiejętność rozumienia zwerbalizowanych zasad zabawy o charakterze społecznym $^{13}$. Dzięki zabawie $\mathrm{u}$ dzieci rozwija się myślenie symboliczne, uruchamia się wyobraźnia, zabawki mogą reprezentować prawdziwe przedmioty. Dziecko uczy się działania z przedmiotem, sprawdza, jak można go wykorzystać i jakie ma właściwości. Po-

11 Ibidem.

${ }_{12}$ M. Przetacznikowa, H. Spionek, Zabawa jako typowa forma działalności małego dziecka, [w:] Psychologia rozwojowa dzieci i młodzieży, red. M. Żebrowska, PWN, Warszawa 1982, s. 120-132.

13 J. Cieszyńska, M. Korendo, Wczesna interwencja terapeutyczna. Stymulacja rozwoju dziecka. Od noworodka da 6 roku życia, Wydawnictwo Edukacyjne, Kraków 2014. 
przez zabawy tematyczne wypróbowuje różne scenariusze, które wdraża w życie, uczy się adekwatnych zachowań i relacji międzyludzkich ${ }^{14}$. Zdaniem Lwa Wygotskiego zabawy wyobrażeniowe są najwyższą formą zabawy, która prowadzi do rozwoju zarówno wyobraźni, jak i myślenia abstrakcyjnego ${ }^{15}$. Dziecko rozwijające się prawidłowo nie zastanawia się nad sensem realizowanej przez nie zabawy. Odczuwa instynktowną potrzebę wchodzenia w interakcję ze światem, ludźmi, potrzebę tworzenia, przeżywania, doświadczania otaczającej go rzeczywistości. Obserwując malucha, który np. zmaga się nie wiadomo który raz z układaniem przewracającej się piramidy z klocków lub czteroletniej dziewczynki, która gotuje dla lalek spagetti z wody, farby i kawałków bibuły - widać wyraźnie, jakie podwaliny dla dalszego rozwoju tworzą się w tym czasie.

Odmiennie przedstawiają się umiejętności zabawy w przypadku dzieci z zaburzeniami z autystycznego spektrum. „Dziecko autystyczne mało lub prawie wcale nie interesuje się otoczeniem, nie bada go i nie odkrywa. Nie bawi się zabawkami w sposób typowy, zgodnie $\mathrm{z}$ ich przeznaczeniem"16. Zabawa w tej grupie jest najczęściej „dziwna”, tj. o zaskakującej, nietypowej formie i/lub przebiegu. Dziecko może bawić się zupełnie innymi przedmiotami lub wykorzystywać przedmioty w nietypowy sposób. Zamiast misia, przytulanki dziecko nie rozstaje się z kombinerkami, łyżka służy do stukania o meble, dziecko może rozdzierać i rozrzucać chusteczki higieniczne, gazety rozdzielać na paseczki, spędzać czas w łazience, obserwując wirujące $\mathrm{w}$ pralce pranie, wprowadzać przedmioty w ruch rotacyjny, wpatrywać się $\mathrm{w}$ cienie na ścianie przez wiele godzin itp. Zabawki wykorzystywane są schematycznie np. puzzle układane są odwrotnie, obrazkiem do dołu, obrazki z loteryjki układane w pionowe, równiutkie wieże, a samochody ustawione

${ }^{14} \mathrm{~J}$. Moor, Śmiech, zabawa i nauka z dziećmi o profilu autystycznym, Wydawnictwo Cyklady, Łódź - Warszawa 2006.

${ }^{15}$ E. Filipiak, Nauczanie rozwijające we wczesnej edukacji wedtug Lwa S. Wygotskiego. Od teorii do zmiany w praktyce, Akademia Centrum kreatywności, Bydgoszcz 2015.

${ }^{16}$ A. Bryńska, G. Jagielska, J. Komender, Autyzm i zespót Aspergera, Wydawnictwo Lekarskie PZWL, Warszawa 2009. 
jeden za drugim $\mathrm{w}$ niezwykle długim rządku. Często też zmiana tego ułożenia przez rodzica, nauczyciela czy terapeutę skutkuje złością, agresją lub autoagresją ${ }^{17}$. Wśród dzieci z ASD charakterystyczny jest brak zabawy z udawaniem, brak potrzeby kooperowania $\mathrm{w}$ zabawie $\mathrm{z}$ innymi rówieśnikami. Poziom nasilenia trudności będzie zależny od różnorodnych czynników, które wymienia Julia Moor. Należą do nich min.:

- problemy w mowie i komunikacji, charakteryzujące się opóźnieniem rozwoju mowy, nieprawidłowościami, brakiem rozumienia mowy itp.,

- trudności z odczytywaniem i interpretacją przekazów niewerbalnych takich jak mimika twarzy, postawa ciała, ton głosu itp.,

- nieprawidłowości w kontaktach międzyludzkich, niechęć i nieumiejętność do dzielenia przestrzeni, dzielenia się swoimi przeżyciami i doświadczeniami,

- problemy z uruchomieniem wyobraźni, odczytywaniem zmyślonych sytuacji, co skutkować może obsesyjnym powtarzaniem jednej i tej samej czynności ${ }^{18}$.

Przyglądając się zabawie dzieci z ASD, można zauważyć zdecydowaną większość aktywności mających charakter autostymulacji, schematów, braku zaplanowanej aktywności czy zupełnie brak wykorzystywania zabawek zgodnie z ich przeznaczeniem. Dziecko $\mathrm{z}$ autyzmem wybiera chętniej aktywność z przedmiotem niż z drugą osobą czy choćby z koniecznością respektowania jakichś społecznych umów, zasad czy konwencji. Dużą większą przyjemność ma $\mathrm{z}$ toczenia samochodu $\mathrm{w}$ przód i w tył, przyglądając się kręcącym się kołom niż z parkowania samochodu na zabawkowym parkingu, ładowaniem koledze klocków do ciężarówki, ściganiem się po torze ${ }^{19}$. Dziewczynka bawi się pluszową sową, ale macha jej skrzydełkami w polu widzenia albo przesuwa je po buzi. Chłopiec

17 Podawane w artykule przykłady pochodzą z własnej praktyki terapeutycznej.

$18 \mathrm{~J}$. Moor, op. cit.

${ }^{19}$ E. Pisula, Narzędzia przesiewowe pomocne w rozpoznawaniu ryzyka autyzmu u dzieci w wieku do trzech lat, „Konteksty Pedagogiczne” 2013, nr 1. 
układa układankę, ale elementy są ułożone pionowo i poziomo według kolorów lub wielkości, a nie np. według kategorii czy w odpowiednich otworach; bawi się samolotem, lecz głównie kręci śmigłem, a nie udaje latania maszyną itd. Przykłady takich działań można mnożyć w nieskończoność.

U dzieci z ASD zdecydowanie częściej brakuje zabaw z udawaniem, zabaw tematycznych czy zabaw $\mathrm{z}$ wyobraźnią. Dzieciom $\mathrm{z}$ autyzmem trudno jest wyobrazić sobie, że klocek może być samolotem, woreczek z grochem rybką, piłka pomarańczą. „W badaniach Barona-Cohena zaledwie $20 \%$ dzieci autystycznych zdolnych było do zabawy z pozorowanie (zabawy z udawaniem). Zdolności takie przejawiało $80 \%$ dzieci z zespołem Downa" 20 . Zabawa dzieci z ASD może przybierać charakter zabawy funkcjonalnej, co oznacza, że mogą bawić się zabawkami zgodnie z ich przeznaczeniem lub często zabawy sensomotorycznej. Dziecko jest zainteresowane sensorycznymi właściwościami zabawki: wącha ją, liże, wkłada do ust, ogląda pod różnym kątem. Jednak u dzieci z autyzmem występują również inne rodzaje zabawy. W tej grupie dzieci może pojawiać się zabawa funkcjonalna, konstrukcyjna, zabawa z udawaniem czy zabawa symboliczna ${ }^{21}$. Możliwości dziecka będą $\mathrm{w}$ dużym stopniu uzależnione od możliwości komunikacyjnych, sprawności intelektualnej czy rozwiniętej teorii umysłu²2.

Obserwując dzieci $\mathrm{z}$ autyzmem $\mathrm{w}$ grupie rówieśniczej, można wyraźnie zauważyć, że nie wchodzą one $\mathrm{w}$ interakcje $\mathrm{z}$ innymi kolegami czy koleżankami z grupy. Często zainteresowania dzieci z autyzmem zupełnie nie odpowiadają zainteresowaniu ich rówieśników bez zaburzeń. Duża grupa dzieci przejawia od najwcześniejszych lat zainteresowania czy wręcz fascynacje literami i cyframi. Szybko je zapamiętują, rozpoznają na każdym kroku, mogą je układać w kolejności, być niezwykle przywiązane do jednej wybranej (niezwykle fascynujące są dla danego dziecka np. akurat 4, 5 i 8).

\footnotetext{
${ }^{20}$ Ibidem.

21 E. Pisula, Małe dziecko z autyzmem...

22 Ibidem.
} 
Dziecko rozpoznaje już od bardzo wczesnego okresu daną cyfrę, chodzi z nią niczym z talizmanem, uwielbia układanki bądź puzzle z cyframi, zegary, kalendarze, autobusy czy tramwaje oznaczone odpowiednim numerem. Ogląda książkę, ale tylko na tej stronie, która ma odpowiedni numer. Podobnie sytuacja wygląda z obsesją na punkcie liter. Małe dziecko od wczesnego okresu wykazuje niezwykłą fascynacje np. programami w telewizji (zapisem logo nazwy programu np. TVN czy POLSAT). Ogląda napisy, rozpoznaje je, odnajduje $\mathrm{w}$ gazecie telewizyjnej, na wczesnym etapie próbuje przepisywać litery, łącząc je w całość. Często też obserwuje i rozpoznaje napisy - etykiety supermarketów, sieciowych restauracji czy sklepów. Dziecko odczytuje nazwy, układa je z klocków lub liter. Charakterystyczne są upodobania do układania, odtwarzania czy powtarzania alfabetu. Szczególnie często można zaobserwować zamiłowania do obcojęzycznych piosenek dla dzieci, gdzie wymieniany jest alfabet $\mathrm{w}$ kolejności. Wraz $\mathrm{z}$ wiekiem upodobania mogą się nie zmieniać, ale może nie mieć to przełożenia na właściwości funkcjonalne, np. dziecko nie wykorzystuje tych fascynacji do nauki czytania. Często celem nadrzędnym jest nie poznanie liter czy cyfr, lecz sam akt ułożenia, dopasowania. Czasami jednak litery dają dziecku możliwość układania wyrazów, nazw, które są dla nich wyjątkowo ważne. Dziecko układa tytuły filmów, nazwy telefonów komórkowych, informacje z pilota typu: play, stop, nazwy dinozaurów, zdecydowanie rzadziej imiona swoje lub kogoś z członków rodziny. Dodatkowo $\mathrm{w}$ tych kategoriach zainteresowań mamy schemat, powtarzalność i przewidywalność, świat, który dla dzieci z ASD jest bezpieczny i satysfakcjonujący ${ }^{23}$.

Świadomość trudności dzieci z autyzmem w zabawie powoduje zwiększenie zainteresowania naukowców tą formą aktywności, choć pozornie kłóci się potrzeba strukturalizacji trenowania założonych umiejętności $\mathrm{z}$ potrzebą stymulowania spontanicznych zachowań zabawowych. W literaturze istnieją propozycje terapeu-

${ }^{23}$ Obserwacje własne. Zob. także: M. Charbicka, Dziecko z Zespotem Aspergera, Difin, Warszawa 2015. 
tyczne, które próbują powiązać te dwa rozbieżne cele: koncepcja Floor Time Grennspana czy też model IPG (Integrated Play Group Model) Wolfberga i Schulera ${ }^{24}$, oraz kilka innych, jednak w tym opracowaniu istotne jest spojrzenie na zabawę dziecka nie przez pryzmat celu, a więc i modelu terapeutycznego, lecz jako na aktywność autoteliczną: aktywność zabawową, jako doświadczenie, którego - jak można przypuszczać - bardzo brakuje w ustrukturyzowanym życiu dziecka z autyzmem. Stanowi to deficyt konieczny do zniwelowania $\mathrm{w}$ działaniach przede wszystkim wychowawczych, by nie trzeba było zajmować się nią aż tak intensywnie poprzez terapię, która powinna mieć jednak charakter interwencyjny. $\mathrm{W}$ procesie terapeutycznym dzieciom $\mathrm{z}$ autyzmem najczęściej proponuje się zabawy, które mają charakter edukacyjny: manipulacyjne, dydaktyczne czy ruchowe. $\mathrm{W}$ sytuacjach domowych, również rodzice - ukierunkowani przez terapeutów - koncentrują się silniej na procesie terapeutycznym, większy nacisk kładą w zabawie na rozwijanie umiejętności, które mają wymiar dydaktyczny niż na spontaniczność zachowań. Warto to zmienić, stąd zrodził się pomysł projektu badawczego podnoszącego wiedzę o zabawie dziecka z ASD jako aktywności pożądanej jako sama w sobie. Wymaga to jednak przede wszystkim rozpoznania specyfiki zabawy tych dzieci.

\section{Metodologia badań własnych}

Obserwacja zabawy dzieci z ASD, ich spontanicznych zachowań czy interakcji odbywała się $\mathrm{w}$ czasie 10 miesięcy podczas udziału w zajęciach realizowanych na terenie łódzkiego przedszkola terapeutycznego dla dzieci z autyzmem. Grupa 12 dzieci uczęszczających do przedszkola, to dzieci w przedziale wiekowym od 2 do 8 lat. Wszystkie dzieci przyjęte są do przedszkola na podstawie orzeczenia o potrzebie kształcenia specjalnego wydanego $\mathrm{z}$ uwagi na

24 J. Lantz, Play time: An examination of play intervention strategies for children with autism spectrum disorders, "The Reporter" 2001, 6(3), s. 1-7. 
autyzm. Część uczniów ma orzeczenie informujące o niepełnosprawności sprzężonej: autyzm i niepełnosprawność intelektualna. Obserwacja odbywała się tylko w sytuacjach spontanicznej i niezorganizowanej aktywności uczniów, najczęściej podczas zajęć tzw. opiekuńczo-wychowawczych, kiedy dziecko ma „czas wolny” dla siebie. W tym okresie dzieci miały swobodny dostęp do zabawek, a osoby dorosłe nie narzucały im żadnych zadań. Podczas obserwacji zapisywane były zachowania dziecka, to, co dziecko robiło, jak się zachowywało, jakie aktywności wybierało ${ }^{25}$. W drugiej kolumnie przedstawione są zachowania dzieci z typowym rozwojem (dzieci pracowników, rodzeństwo), które pojawiały się na zajęciach w przedszkolu, w którym prowadzono badania. Obserwację nieskategoryzowaną, w kategoriach metodologicznych określono jako próbki zdarzeń. Miała ona charakter naturalny i niejawny, tj. dzieci nie wiedziały, że są obserwowane, ale były przyzwyczajone do stałej obecności terapeuty, jako naturalnej sytuacji w czasie ich pobytu w przedszkolu.

Zestawienie zaobserwowanych aktywności w zabawach przedstawia tabela nr 1.

Uzupełnieniem badań obserwacyjnych dzieci przebywających w przedszkolu były informacje na temat grupy dzieci z ASD, badanych narzędziem ADOS-226. Badania te były wykonywane wśród dzieci z diagnozą autyzmu, biorących udział w ogólnopolskim projekcie adaptacyjnym i walidacyjnym narzędzia ADOS-2 oraz w gru-

25 Obserwacje prowadzone były w Przedszkolu Terapeutycznym dla Dzieci z Autyzmem z Łodzi.

${ }^{26}$ Autism Diagnostic Observation Schedule-2 narzędzie do diagnozowania i oceniania objawów autyzmu. W latach 2013-2016 w Polsce realizowany był projekcie badawczym, mający na celu walidację narzędzia i jego adaptacje do polskich norm. Projekt realizowany był pod kierownictwem prof. dr hab. Ewy Pisuli i dr Izabeli Chojnickiej z Wydziału Psychologii Uniwersytetu Warszawskiego, w ramach grantu badawczego przyznanego przez Państwowy Fundusz Rehabilitacji Osób Niepełnosprawnych, współfinansowanego ze środków UW. W projekcie brały udział organizacje działające na rzecz osób z ASD. Autorka jest jedną z terapeutek włączonych do badań. Opis wyników dzieci objętych terapią własną wykorzystano za zgodą kierownictwa projektu, zgodnie z warunkami uczestnictwa w nim. 
Tabela 1. Zestawienie aktywności dzieci w przedszkolu terapeutycznym - przykłady obserwowanych zabaw u dzieci $\mathrm{z}$ autyzmem oraz zabawy dzieci $\mathrm{z}$ typowym rozwojem obserwowanych w spontanicznej aktywności (źródło: badania własne)

\begin{tabular}{|c|c|c|c|}
\hline $\begin{array}{l}\text { Wiek } \\
\text { dzieci }\end{array}$ & \begin{tabular}{|c|} 
Liczba \\
obserwowanych \\
dzieci z ASD \\
\end{tabular} & $\begin{array}{c}\text { Najczęściej wybierane aktywności } \\
\text { dziecka z autyzmem podczas } \\
\text { swobodnej zabawy }\end{array}$ & $\begin{array}{c}\text { Najczęściej wybierane aktywności } \\
\text { dziecka z typowym rozwojem } \\
\text { podczas swobodnej zabawy }\end{array}$ \\
\hline 1 & 2 & 3 & 4 \\
\hline 2-3 lata & 2 & $\begin{array}{l}\text { Bawi się grającą i świecącą zabaw- } \\
\text { ką, wielokrotnie uruchomiając ją } \\
\text { i powtarzając tę czynność, wkłada } \\
\text { plastikowe owoce do garnka i mie- } \\
\text { sza je przez długi czas, czynność } \\
\text { powtarza wielokrotnie, w sytuacji, } \\
\text { kiedy sobie nie radzi, ciągnie rękę } \\
\text { osoby dorosłej, nie nawiązując kon- } \\
\text { taktu wzrokowego, wspina się na } \\
\text { krzesło i na stolik, jest bardzo ak- } \\
\text { tywny ruchowo, wielokrotnie wy- } \\
\text { korzystuje zabawki dźwiękowo- } \\
\text {-świetlne, uruchomiając je obsesyj- } \\
\text { nie, liże zabawki, wkłada je do ust }\end{array}$ & $\begin{array}{l}\text { Eksploruje przestrzeń, jest ciekawe } \\
\text { wszystkich proponowanych mu } \\
\text { aktywności, wchodzi w tunel za } \\
\text { piłką, poszukuje wsparcia u mamy, } \\
\text { jeżeli coś mu się nie udaje, nakła- } \\
\text { da koła na piramidę, podaje doro- } \\
\text { słemu, żeby nakładał razem z nim, } \\
\text { miesza w pojemniku materiał syp- } \\
\text { ki, nasypuje do pudełek, buduje } \\
\text { wieżę, układa piramidę, wkłada po- } \\
\text { jemniki od najmniejszego do } \\
\text { największego }\end{array}$ \\
\hline 3-4 lata & 2 & $\begin{array}{l}\text { Chodzi po sali bez celu, wkłada } \\
\text { zabawki do ust, buczy, mruczy, } \\
\text { depcze po zabawkach, które się } \\
\text { wysypały, rozkłada dłonie i spo- } \\
\text { gląda pod światło, wkłada ręce do } \\
\text { buzi, stuka klockiem o podłogę, } \\
\text { drzwi }\end{array}$ & $\begin{array}{l}\text { Bazgrze kredkami, słucha czyta- } \\
\text { nych książek, ogląda obrazki, } \\
\text { chętnie maluje farbami, bawi się } \\
\text { zabawkową kuchnią i garnkami, } \\
\text { rozkłada na talerze, rozdaje doro- } \\
\text { słym, buduje tor dla drewnianych } \\
\text { pociągów, lepi kulki i wałki z pla- } \\
\text { steliny, nazywa je (wąż, ryba itp.) }\end{array}$ \\
\hline 5-6 lat & 6 & $\begin{array}{l}\text { Bawi się plastikowymi i materia- } \\
\text { łowymi owocami, chętnie ogląda } \\
\text { ulubioną bajkę, ugniata ciastolinę } \\
\text { łączy ze sobą różne rodzaje mas } \\
\text { plastycznych, biega bez celu po } \\
\text { sali przedszkolnej, skacze, skacze } \\
\text { na piłce, układa wieloelementowe } \\
\text { puzzle, śpiewa piosenki z bajki, } \\
\text { powtarza całe frazy. } \\
\text { Podrzuca do góry przedmioty i za- } \\
\text { bawki, wprowadza je w ruch wi- } \\
\text { rowy w dłoni }\end{array}$ & $\begin{array}{l}\text { Bawi się klockami Lego, buduje } \\
\text { budowle: bazy, zamki, garaże, lepi } \\
\text { z modeliny figurki dinozaurów, } \\
\text { gra w gry planszowe i zagadki, } \\
\text { rysuje kredkami i koloruje na in- } \\
\text { teresujące je tematy, takie jak zwie- } \\
\text { rzęta, dinozaury, angażuje do za- } \\
\text { bawy dorosłe osoby z rodziny, } \\
\text { walczy na miecze, wspina się na } \\
\text { meble, chowa się i domaga się, } \\
\text { żeby go szukać }\end{array}$ \\
\hline
\end{tabular}


cd. tab. 1

\begin{tabular}{|c|c|c|c|}
\hline 1 & 2 & 3 & 4 \\
\hline $7-8$ lat & 2 & $\begin{array}{l}\text { Siedzi lub leży na podłodze, cza- } \\
\text { sami czyta książki, wyjmuje i układa } \\
\text { kilku elementowe puzzle dla młod- } \\
\text { szych dzieci, nie inicjuje zabawy, } \\
\text { oczekuje na propozycję dorosłego, } \\
\text { bawi się cyframi, układając je w ko- } \\
\text { lejności; najchętniej leży i kiwa } \\
\text { się, tnie nożyczkami kartki, gazety } \\
\text { bez celu na drobne kawałki, wkła- } \\
\text { da plastikowe warzywa do garn- } \\
\text { ka, często wkłada do buzi za- } \\
\text { bawki, przedmioty, układa puzzle } \\
\text { z } 25 \text { elementów }\end{array}$ & $\begin{array}{l}\text { Kolekcjonuje figurki i gadżety z ulu- } \\
\text { bionego filmu, opowiada z dużą } \\
\text { ekspresją o swoich bohaterach, chce } \\
\text { się bawić z dorosłym w odtwa- } \\
\text { rzanie scen z filmu, wymyśla i bu- } \\
\text { duje statek kosmiczny, wykorzy- } \\
\text { stując przedmioty w otoczeniu; } \\
\text { rysuje sceny z ulubionych filmów } \\
\text { i z ulubionymi bohaterami, wy- } \\
\text { myśla obrazki }\end{array}$ \\
\hline
\end{tabular}

pie kontrolnej dzieci z typowym rozwojem. Narzędzie to wykorzystywane jest na świecie jako tzw. "złoty standard diagnostyczny" w rozpoznawaniu zaburzeń w rozwoju dzieci27. ADOS-2 jest wystandaryzowanym i częściowo ustrukturyzowanym protokołem obserwacji przydatnym w diagnozie klinicznej, a także stosowanym na potrzeby badań naukowych. Narzędzie składa się z czterech modułów, których wybór warunkowany jest wiekiem oraz kompetencjami językowymi badanego, a także z modułu służącego do badania dzieci w bardzo wczesnym dzieciństwie (Moduł Toddler). Poszczególne moduły w przedziałach wiekowych przeznaczone dla dzieci młodszych skoncentrowane są na badaniach takich umiejętności jak:

- język i komunikacja,

- wzajemność interakcji społecznych,

- zabawa,

- zachowania stereotypowe i sztywne wzorce zachowań i zainteresowań,

- inne zachowania odbiegające od normy 28.

27 I. Chojnicka, E. Pisula E. ADOS-2 Polska adaptacja, Pracownia Testów Psychologicznych, Warszawa 2017.

${ }^{28}$ I. Chojnicka, Polska wersja narzędzia obserwacyjnego do diagnozowania autyzmu ADOS, „Psychiatria Polska” 2012, tom XLVI, numer 5. 
Tabela 2. Wyniki obserwacji dzieci badanych narzędziem ADOS-229

\begin{tabular}{|c|c|c|}
\hline $\begin{array}{l}\text { Rodzaj modu- } \\
\text { łu/przedział } \\
\text { wiekowy, wiek }\end{array}$ & Wyniki obserwacji dziecka z ASD & Wyniki obserwacji dziecka bez ASD \\
\hline 1 & 2 & 3 \\
\hline $\begin{array}{l}\text { ADOS-2 moduł T } \\
18-30 \text { miesięcy }\end{array}$ & $\begin{array}{l}\text { Kręci kołami od samochodu, pociera } \\
\text { rękę szorstkim klockiem, obserwuje } \\
\text { toczące się koła, brak zainteresowania } \\
\text { piłką, bańkami, szybko zmienia zain- } \\
\text { teresowanie zabawkami, brak słów }\end{array}$ & $\begin{array}{l}\text { Ogląda różne zabawki, pokazuje je ma- } \\
\text { mie, angażuje mamę do zabawy, oglą- } \\
\text { da torebkę, przedmioty, które do niej } \\
\text { pasują wkłada do torebki, pokazuje } \\
\text { mamie książkę ze zwierzątkami, uda- } \\
\text { je, że rozmawia przez telefon, kilka } \\
\text { słów: mama, lala, co to? Chowa się za } \\
\text { mamę lub szuka u niej schronienia }\end{array}$ \\
\hline $\begin{array}{l}\text { ADOS-2 moduł T } \\
18-30 \text { miesięcy }\end{array}$ & $\begin{array}{l}\text { Układa w rzędzie klocki i auta, wkła- } \\
\text { da zabawki do ust, kręci kółkami od } \\
\text { samochodu, zainteresowany zabaw- } \\
\text { kami grającymi krótko, chodzi po za- } \\
\text { bawkach, brak słów }\end{array}$ & $\begin{array}{l}\text { Ogląda zabawki z zainteresowaniem, } \\
\text { podaje je mamie, angażuje mamę do } \\
\text { zabawy, wspina się do mamy w sy- } \\
\text { tuacjach, kiedy się niepokoi, przynosi } \\
\text { mamie lakę i łyżeczkę z talerzykiem, } \\
\text { karmi mamę i lalkę }\end{array}$ \\
\hline $\begin{array}{l}\text { ADOS-2 moduł } 1 \\
3-4 \text { lata }\end{array}$ & $\begin{array}{l}\text { Skacze po kolorowych kołach, wy- } \\
\text { mienia kolory, przelicza misie z za- } \\
\text { bawce przyczynowo-skutkowej, chodzi } \\
\text { w kółko po pokoju, nazywa zwierząt- } \\
\text { ka w książce, przelicza klocki, mówi } \\
\text { kilka słów }\end{array}$ & $\begin{array}{l}\text { Rozkłada naczynia, układa na nich } \\
\text { kawałki włóczki, rozkłada na talerzach } \\
\text { sztućce, rozdaje dorosłym stawia przed } \\
\text { lalką udaje, że je, spogląda, czy wszy- } \\
\text { scy dorośli zaangażowani są w zabawę, } \\
\text { ogląda wszystkie zabawki, podaje opie- } \\
\text { kunowi zabawki przyczynowo-skutko- } \\
\text { we, angażuje opiekuna i diagnostę } \\
\text { w zabawę, brak mowy werbalnej }\end{array}$ \\
\hline $\begin{array}{l}\text { ADOS-2 moduł } 1 \\
4-4,8 \text { lat }\end{array}$ & $\begin{array}{l}\text { Kładzie się na podłodze i płacze } \\
\text { przez większość czasu, głównie za- } \\
\text { interesowany jest zabawkami grają- } \\
\text { cymi i wydającymi dźwięki, chodzi } \\
\text { po zabawkach, krótko zainteresowa- } \\
\text { ny każdą zabawką, wkłada zabawki } \\
\text { do buzi, zabawa zabawkami przyczy- } \\
\text { nowo-skutkowymi przez krótki czas, } \\
\text { brak mowy }\end{array}$ & $\begin{array}{l}\text { Ogląda wszystkie przedmioty z zain- } \\
\text { teresowaniem, pokazuje mamie z da- } \\
\text { leka, nakłada klocki do ciężarówki, } \\
\text { angażuje do zabawy mamę i diag- } \\
\text { nostę, naprawia auto, udaje, że dzw- } \\
\text { oni telefonem. Zadaje pytania o za- } \\
\text { bawki, które pokazuje mamie }\end{array}$ \\
\hline
\end{tabular}

${ }^{29}$ Poruszane wcześniej. 
cd. tab. 2

\begin{tabular}{|c|c|c|}
\hline 1 & 2 & 3 \\
\hline $\begin{array}{l}\text { ADOS-2 moduł } 2 \\
5-7 \text { lat }\end{array}$ & $\begin{array}{l}\text { Zainteresowany głównie zabawkami } \\
\text { dźwiękowymi przyczynowo-skutko- } \\
\text { wymi, wkłada do ust telefon, układa } \\
\text { autka w rządku i kręci kółkami od } \\
\text { auta }\end{array}$ & $\begin{array}{l}\mathrm{Z} \text { zainteresowaniem ogląda zabawki, } \\
\text { bawi się autem, ładuje klocki do sa- } \\
\text { mochodu, zawozi je i buduje z nich } \\
\text { wieżę, komentuje, co robi, naprawia } \\
\text { auto, angażuje do zabawy diagnostę, } \\
\text { zadaje pytania o zabawki, jest zainte- } \\
\text { resowany wszystkimi }\end{array}$ \\
\hline
\end{tabular}

Źródło: badania własne

W algorytmie diagnostycznym zawarte są określone zadania, które zostały przypisane do dwóch kategorii. Dla potrzeb niniejszego artykułu wykorzystano badania wykonane modułem 1 i 2 . Moduł 1 przeznaczony jest dla dzieci w wieku 31 miesięcy i starszych, których rozwój językowy znajduje się na poziomie przedwerbalnym lub występuje kilka pojedynczych słów. Moduł 2 wykorzystywany jest do prowadzenia diagnozy dzieci posługujących się mowa zdaniową, najczęściej w okresie przedszkolnym. Obydwa moduły zawierają zadania w części C protokołu, dotyczące zabawy. W obu badaniach oceniana jest „Funkcjonalna zabawa przedmiotami oraz wyobraźnia/kreatywność" 30 . Pozycje te oceniane są podczas zabaw z wykorzystaniem zabawek - miniatur reprezentujących obiekty rzeczywiste. Dziecko bawi się spontanicznie, symbolicznie, na niby. Ocena dokonywana jest na skali od 0 do 3 punktów, gdzie 0 jest oceną wskazującą na prawidłowości w danej aktywności. Ocenie podlega elastyczne i kreatywne użycie zabawek, pomysły wykorzystywanie ich w sposób symboliczny, zabawa tematyczna (np. urodziny) i spontaniczność31. Porównanie aktywności zabawowej dzieci w obu grupach badanych ADOS-2 w projekcie walidacyjnym przedstawia tabela $\mathrm{nr}$ 2. Obserwacja standaryzowana techniką próbek zdarzeń miała również charakter naturalny, nie-

${ }^{30}$ E. Pisula, I. Chojnicka, op. cit.

31 Ibidem. 
jawny. $\mathrm{W}$ tabeli 2. zaprezentowano badania pięciorga dzieci $\mathrm{z}$ rozpoznaniem autyzmu, określonych jako ASD, oraz pięciorga dzieci z grupy kontrolnej, określonych jako NON-ASD.

Informacje zawarte $\mathrm{w}$ tabeli zawierają zapis $\mathrm{z}$ arkuszy obserwacji dzieci w zadaniu, które występuje we wszystkich trzech zaprezentowanych modułach. Próba ta zakłada swobodną zabawę dziecka i w dwóch pierwszych modułach realizowana jest na początku badania, zaś $\mathrm{w}$ module $2 \mathrm{w}$ połowie wykonywanych przez dziecko zadań. Jak wynika z próbek, tabela 1. i 2. podkreślają różnice w zabawie pomiędzy dzieckiem o typowym rozwoju a dzieckiem z ASD. Również widoczne są pewne charakterystyczne cechy zabawy w ASD, które są porównywalne w obu badaniach. Na tej nielicznej próbie widać wyraźnie nieprawidłowości w grupie dzieci z ASD.

\section{Podsumowanie}

Zabawie dzieci z ASD można poświęcić wiele miejsca, gdyż jest to szeroki i obiecujący teoretycznie i praktycznie obszar badawczy. Porównując ją z zabawą rówieśników, oprócz opisanej nietypowości, wysuwa się refleksja nad podstawowym aspektem: zabawa jest aktem społecznym. Dzieci bawią się z innymi dziećmi i czerpią $\mathrm{z}$ tego przyjemność oraz naukę do poznawania świata. Ich zabaw zmienia się i ewoluuje wraz z wiekiem i wraz ze zdobywaniem nowych doświadczeń.

Dziecko z ASD bawi się najczęściej w sposób nietypowy, nie wchodzi $\mathrm{w}$ interakcje społeczne $\mathrm{z}$ rówieśnikami, nie ma bezpośredniej możliwości nabycia tych umiejętności, które kształtują się podczas zabawy w typowym rozwoju. Jak zatem może zafunkcjonować $\mathrm{w}$ świecie dzieci, skoro nie ma $\mathrm{z}$ nimi płaszczyzny porozumienia? Jeżeli zabawa dla dzieci odgrywa tak istotną rolę, a w przypadku ASD ujawnia tak poważny deficyt kluczowych kompetencji, czy nie warto byłoby poświęcić więcej czasu w procesie terapii na jej rozwijanie? Chodzi przy tym - raz jeszcze podkreślam - o zabawę jako aktywność autoteliczną, nie instrumentalną, a więc często nawet pseudo-zabawę. 
Analizując proces oddziaływań terapeutycznych ukierunkowany na dziecko we wczesnej interwencji, zarówno terapeuci, specjaliści, wychowawcy, nauczyciele, jak i rodzice przywiązują niezwykłą wagę do terapii. Często koncentrują się na terapii jako ustrukturyzowanych oddziaływaniach edukacyjnych i przywiązują dużą może zbyt dużą? - wagę do rozwijania takich konkretnych umiejętności, jak np. rozpoznawanie figur, liter, kolorów, liczby itp. Małe dziecko z ASD dopasowuje identyczne obrazki, rozpoznaje różnice, emocje, usprawnia grafomotorykę, uczy się czytać, liczyć, być grzecznym... Ma to mu zastąpić zabawę. Czy nie pogłębia deficytu spontaniczności? Pytanie te wymagają oczywiście dalszych, pogłębionych badań, lecz zgromadzone obserwacje uzasadniają ten niepokój.

Zabawy dla dzieci z autyzmem mają charakter terapeutyczny, dlatego chętnie wykorzystywane są $\mathrm{w}$ terapii. Umiejętność bawienia się schodzi jednak na dalszy plan, gdyż zabawa będzie nadal kojarzyć się z terapią. W rezultacie tego dziecko z ASD ma opanowane wiele treści edukacyjnych, z których nigdy w życiu może nie skorzystać. Podobnie później, gdy idzie do szkoły, okazuje się, że nie potrafi wejść $\mathrm{w}$ interakcję z kolegą, bo dzieci w tym wieku jeszcze się bawią: ganiają się, grają w "berka”, bawią się w "chowanego", poszturchują z kolegami - czasem żartując, czasem się pokłócą, ale za chwilę znowu wymieniają się posiadanymi kartami, chwalą się nowymi figurkami z klocków Lego czy naklejkami z postaciami $\mathrm{z}$ modnego filmu. Czynności te polegają na spontanicznej wymianie społecznej. Tymczasem dziecko $\mathrm{z}$ autyzmem przeżywa frustracje w związku z przerwą, bo nie umie zaistnieć w grupie swoich kolegów i koleżanek. Nie wie, jak interpretować zachowania innych i co robić w wolnym czasie, bo od najwcześniejszych lat jest "wspierane przez dorosłych", którzy towarzyszą mu na każdym kroku, z gotowym algorytmem czynności. $Z$ bezradności i w napięciu podskakuje więc w kącie albo biega bez celu, trzepocząc rękoma.

Analizując korzyści, jakie przynoszą „prawdziwe”, spontaniczne zabawy dziecięce, może należałoby wprowadzić je również do programu terapeutycznego małego dziecka, u którego zdiagnozo- 
wano zaburzenia ze spektrum autyzmu, także dla kształtowania specyficznych umiejętności zabawowych. „Dzieci uczą się przez zabawę i tak powinna wyglądać nauka w ramach programu wczesnej interwencji" 32 . Należy jednak pamiętać, że w autyzmie obszar kompetencji społecznych rozwija się nieprawidłowo. Dlatego w literaturze przedmiotu podkreśla się rolę oddziaływań wspólnie z dzieckiem - choćby w zorganizowaniu przestrzeni aktywności na podłodze. Z doświadczeń terapeutycznych wiadomo, że nie zawsze łatwo "sprowadzićc rodzica do poziomu podłogi, co znakomicie odzwierciedla intencja wspomnianej już metody terapeutycznej floor time. Podłoga, ale także ogród, trawnik, łąka, może stać się symboliczną przestrzenią otwarcia środowiska (dla) zabawy ${ }^{33}$. James Ball podkreśla, że „(...) to czego doświadcza dziecko i co ma na celu naukę, powinno się koncentrować wokół zabawy.(...) Środowisko zabawy powinno być pierwszym i najważniejszym otoczeniem dziecka" 34 .

W procesie terapii dziecka $\mathrm{z}$ autyzmem sesja terapeutyczna powinna być prowadzona w taki sposób, aby obniżyć poziom lęku i utrzymać wysoki poziom motywacji dziecka. Tylko wówczas może ono się uczyć korzystając z tego procesu w pełni. Terapeuci powinni zadbać o to, aby „terapia była tak przyjemna i naturalna, jak to tylko możliwe. (...) Powinna być zabawna i przyjemna, a jednocześnie umożliwiać dziecku naukę"35.

Deficytowych obszarów w autyzmie jest bardzo dużo. U każdego dziecka będą one przybierać różne formy i różny poziom natężenia cech. W świetle współczesnych badań dotyczących kluczowej kwestii umiejętności społecznych oraz teorii umysłu dzieci z autyzmem, znaczenie rozwojowe zabawy wydaje się wysoce uprawdo-

32 J. Ball, Autyzm a wczesna interwencja. Rzeczowe pytania, życiowe odpowiedzi, Wydawnictwo Harmonia Universalis, Gdańsk 2016.

${ }_{33}^{3}$ M. Charbicka, Integracja sensoryczna przez caty rok, Difin, Warszawa 2017.

34 Ibidem.

${ }^{35} \mathrm{~J}$. Knapp, C. Turnbull, Kompletny program terapii SAZ dla osób z zaburzeniami ze spektrum autyzmu w wieku rozwojowym od 1 roku do 4 lat. Podręcznik terapeuty, Wydawnictwo Harmonia Universalis, Gdańsk 2017. 
podobnioną hipotezą ${ }^{36}$, choć wymaga jednak jeszcze dalszych badań. Jednak warto rozważyć kwestię, w którym momencie włączyć w proces terapii spontaniczną aktywność zabawy. Myślę, że warto przekonać do tego pomysłu przede wszystkim rodziców, gdyż często trudno właśnie im zrozumieć, że małe dziecko uczy się życia przez zabawę, a nie tylko siedząc przy stoliku. Potrzeba kształtowania specyficznych umiejętności zabawowych dotyczy często także rodzica, który obarczony rolą współ-terapeuty, zmienia swoje zachowania wobec dziecka - nawet nie zdając sobie $\mathrm{z}$ tego sprawy. Rodzice włączani do pracy z dzieckiem z autyzmem w takiej właśnie roli, obciążani są bowiem odpowiedzialnością za wymierne efekty rozwojowe, wobec czego często nie wykształcają lub zatracają umiejętność spontanicznej zabawy z dzieckiem. Może trzeba pomóc im ją odzyskać...

\section{Bibliografia}

Begeer S., Gevers C., Clifford P. and oth., Theory of Mind Training in Children with Autism: A Randomized Controlled Trial, "Joaurnal of Autism Developmental Disorders" 2011, Aug, 41(8).

ASD Prevalence Study across Europe, http://asdeu.eu/wp-content/uploads/2016/ 09/Poster-ASDEU-Prevalence_AE-Congress.pdf [dostęp: 16.05.2018].

Ball J., Autyzm a wczesna interwencja. Rzeczowe pytania, życiowe odpowiedzi, Wydawnictwo Harmonia Universalis, Gdańsk 2016.

Bryńska A., Jagielska G. Komender J., Autyzm i zespót Aspergera, Wydawnictwo Lekarskie PZWL, Warszawa 2009.

Cieszyńska J. Korendo M., Wczesna interwencja terapeutyczna. Stymulacja rozwoju dziecka. Od noworodka da 6 roku życia, Wydawnictwo Edukacyjne, Kraków 2014.

Charbicka M., Integracja sensoryczna przez caty rok, Difin, Warszawa 2017.

Charbicka M., Dziecko z zespołem Aspergera, Difin, Warszawa 2015.

Chojnicka I., Polska wersja narzędzia obserwacyjnego do diagnozowania autyzmu ADOS, „Psychiatria Polska” 2012, tom XLVI, numer 5.

36 S. Begeer, C. Gevers, P. Clifford and oth., Theory of Mind Training in Children with Autism: A Randomized Controlled Trial, "Joaurnal of Autism Developmental Disorders" 2011, Aug, 41(8). 
Community Report from the Autism and Developmental Disabilities Monitoring (ADDM) Network, https://www.cdc.gov/ncbddd/autism/addm-community-report/docu ments/addm-community-report-2018-h.pdf [dostęp: 12.05.2018].

Filipiak E., Nauczanie rozwijające we wczesnej edukacji wedtug Lwa S. Wygotskiego. Od teorii do zmiany w praktyce, Akademia Centrum kreatywności, Bydgoszcz 2015.

Funded by the Centers for Disease Control and Prevention (CDC), United States Department of Health and Human Services, https:/ /www.cdc.gov [dostęp: 16.05.2018].

Knapp J., Turnbull C., Kompletny program terapii SAZ dla osób z zaburzeniami ze spektrum autyzmu w wieku rozwojowym od 1 roku do 4 lat. Podrecznik terapeuty, Wydawnictwo Harmonia Universalis, Gdańsk 2017.

Lantz, J., Play time: An examination of play intervention strategies for children with autism spectrum disorders, "The Reporter" 2001, 6(3).

Moor J., Śmiech, zabawa i nauka $z$ dziećmi o profilu autystycznym, Wydawnictwo Cyklady, Łódź - Warszawa 2016.

Pisula E., Chojnicka I., ADOS-2 Protokót do diagnozowania zaburzeń ze spektrum autyzmu. Polish edition, Wydawnictwo Mała Litera, Wydawnictwo Cyklady, Hogrefe WPS, USA 2017

Pisula E., Małe dziecko z autyzmem, Diagnoza i terapia, GWP, Gdańsk 2005.

Pisula E., Narzędzia przesiewowe pomocne w rozpoznawaniu ryzyka autyzmu u dzieci w wieku do trzech lat, "Konteksty Pedagogiczne" 2013, nr 1.

Przetacznikowa M., Spionek H., Zabawa jako typowa forma działalności małego dziecka [w:] Psychologia rozwojowa dzieci i młodzieży, red. M. Żebrowskiej, PWN, Warszawa 1982

Rynkiewicz A., Kulik M., Wystandaryzowane, interaktywne narzędzia do diagnozy zaburzeń ze spektrum autyzmu a nowe kryteria diagnostyczne DSM-5, „Psychiatria” 2013, tom 10, nr 2.

SIO https:/ / cie.men.gov.pl/sio-strona-glowna/dane-statystyczne/niepelnosprawnosci-dane-statystyczne/ [dostęp: 16.05.2018]. 